\title{
Teknik Publikasi Media Dakwah Jagat 'Arsy TV
}

\author{
Panji Putrawan Makalalag1, Eunis Khoerunnisa ${ }^{2}$ \\ 1Prodi Komunikasi Penyiaran Islam, Ciamis, Indonesia, \\ panjiputrawan2138@gmail.com.
}

\begin{abstract}
ABSTRAK
Teknik Publikasi Media Dakwah Pada Jagat 'Arsy TV ialah Salah satu teknik media dakwah yang cukup besar pengaruhnya dalam mengembangkan Dakwah Tarekat Qodariyah Naqsyabandiyah Pondok Pesantren Suryalaya Sirnarasa. Tujuan dari penelitian ini adalah untuk mengetahui Bagaimana Publikasi Media Dakwah Pada Jagat 'Arsy TV, Untuk mengetahui Faktor Pendukung dan Penghambat pada Publikasi Media Dakwah Pada Jagat 'Arsy TV, dan Hasil Dari Publikasi Media Dakwah Pada Jagat 'Arsy TV. Adapun pendekatan yang digunakan oleh peneliti adalah pendekatan yang berjenis kualitatif, dengan menggunakan metode analisis isi. Hasil Dari penelitian ini berkaitan dengan 3 jenis teknik Publikasi Media Dakwah Pada Jagat 'Arsy TV, yakni Teknik Audiovisual, Teknik Grafis, dan Teknik Prime Time. Adapun Yang menjadi Faktor pendukung adalah faktor-faktor yang membantu luasnya jangkauan dari informsi yang diunggah, dan faktor pendukung adalah faktor yang menghambat penyebaran informasi. Hasil dari peneltian ini ditnjau dari Jumlah Jangkuan Informasi.
\end{abstract}

Kata Kunci : Teknik Publikasi, Dakwah, Media Sosial.

\section{ABSTRACT}

This journal discusses Da'wah Media Publication Techniques on Jagat 'Arsy TV. The purpose of this study was to find out how the publication of $D a^{\prime}$ wah Media in the Jagat 'Arsy TV, to find out the Supporting and Inhibiting Factors in the 'Arsy TV' Media Publication, and the results of the Da'wah Media Publication on the Jagat 'Arsy TV. The approach used by the researcher is a qualitative type approach, using the method of content analysis. The results of this study are related to 3 types of Media Da'wah Publication techniques on Jagat 'Arsy TV,

Diterima: Agustus 2021. Disetujui: September 2021. Dipublikasikan: September 2021 78 
Teknik Publikasi Media Dakwah Jagat 'Arsy TV namely Audiovisual Techniques, Graphic Techniques, and Prime Time Techniques. The supporting factors are the factors that help the wide reach of the uploaded information, and the supporting factors are the factors that hinder the dissemination of information. The results of this research are reviewed from the Total Outreach of Information.

Keywords : Technique Publications, Da'wah, Social Media

\section{PENDAHULUAN}

Mengajak Orang kepada Kebaikan merupakan sebuah Amalan yang memiliki dampak yang luar biasa, baik itu bagi orang yang mengajak ataupun yang diajak. Mengajak kepada kebaikan dalam Islam dikenal dengan istilah Dakwah. Prof. H. M. Toha Yahya Omar, MA (2004:67) Menjelaskan bahwa, Dakwah menurut Islam ialah mengajak umat manusia kembali ke jalan tuhan dengan menggunakan cara yang bijaksana untuk menggapai kemaslahatan, dan kebahagiaan mereka baik itu didunia dan diakhirat. Istilah dakwah sering didefinisikan kedalam arti yang sama dengan istilah-istilah tabligh, amr ma'ruf nahimunkar, mauidzahhasanah, tabsyir, indzar, washiyyah, tarbiyyah, ta'lim, dan khotbah(Munir \&Alaihi: 17). Padahal kata dakwah itu luas sekali maknanya, sepeti kata ijaz ataupun ithnab. Dakwah didalam al-quran diturunkan ke dalam berbagai macam dan turunan-turunnnya. didalam alquran itu sendiri terulang sebanyak 299 kali. Dimana pengulangan dalam bentuk masdar dikatakan 6 kali, dalam bentuk perintah dikatakan 34 kali, dan dalam bentuk fiil diulang sebnyak 7 kali. Dakwah itu sendiri dalam pengertian umum ialah mengajak kepada umat manusia agar berimana kepada alloh swt dan meyakini nabi muhammad sat sebagai nabinya, serta mengerjakan perintah dan menjauhi larang-larangannya. Diyakini oleh semua umat islam bawah tugas semua nabi termasuk nabi muhammad adalah mendakwahkan agama yaitu islam (Sulton, :13) Islam sebagai agama yang terakhir yang diakui oleh alloh swt, alloh swt telah mengklaimnya dalam ayat suci al-quran, dimana hanya islamlah yang diakui oleh allah swt. (Opik Jamaluddin, 2018: 159-180)

Dalam Berdakwah Rosululloh SAW selalu menggunakan metode yang 
Panji PM, Eunis K

sesuai dengan kondisi lingkungan pada saat itu. Akan beda lagi, apabila Rasululloh SAW berdakwah dengan cara yang keras, maka sudah pasti dakwah nabi akan ditolak pada saat itu, atau Beliau langsung berdakwah secara terang-terangan, sudah pasti beliau akan langsung ditolak secara keras oleh kaum Kafir Quraisy pada saat itu, hal tersebut dikarenakan beliau belum memiliki kekuatan secara kuantitas, untuk berdakwah secara terang-terangan mengingat pada saat itu kaum Kafir Quraisy merupakan penguasa Kota Mekkah.

Islam mengajarkan Metode Dakwah secara bertahap, Perlahan-lahan tapi pasti. Cara Yang diajarkan Islam dalam Berdakwah adalah cara yang sangat bijaksana. Dari Pemamparan diatas dapat ditarik kesimpulan bahwa Islam mengajarkan Metode Dakwah, yang sesuai dengan kondisi, dan perkembangan Zaman. Diantara Metode Dakwah yang Alloh Anjurkan, terdapat dalm Surat An-Nahl ayat 125 :

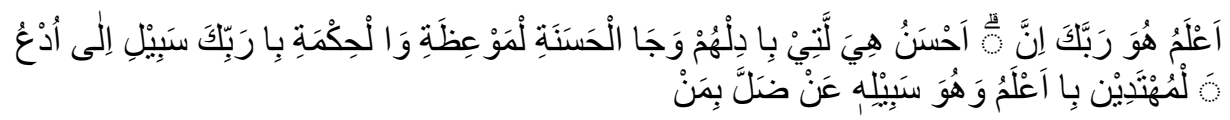

Artinya :

"Serulah (manusia) kepada jalan Tuhanmu dengan hikmah dan pengajaran yang baik, dan berdebatlah dengan mereka dengan cara yang baik. Sesungguhnya Tuhanmu, Dialah yang lebih mengetahui siapa yang sesat dari jalan-Nya dan Dialah yang lebih mengetahui siapa yang mendapat petunjuk."

Di dalam ayat tersebut Allah telah mengajarkan kita cara berdakwah itu dengan kata-kata "BILHIKMATI" yang kita terjemahkan dengan "bijaksana". Al-Hikmati ialah meletakkan sesuatu pada tempatnya. Jadi kitalah yang harus berfikir sekaligus berusha untuk menyusun dan mebuta cara-cara yang mnyesuaikan dengan perkembangan zaman, baik itu melalui tulisan, lisan, atau dengan memberi contoh dengan melakukan hal-hal yang baik, yang sesuai dengan aturan agama $(\mathrm{H}$. M. Toha Yahya Omar 2004:70). Oleh karena demikian Seorang pendakwah mesti mengetahui bagaimana kondisi, dan situasi dari masyarakat yang 
Teknik Publikasi Media Dakwah Jagat 'Arsy TV menjadi objek dari dakwah, tujuannya adalah agar pendakwah dapat mengetahui media apa yang disukai oleh masyarakat, guna membantu dalam menyebarluaskan Pesan dakwah.

Pada Era digital saat ini, Kebutuan Informasi telah menjadi bagian dari kebutuhan pokok di tengah masyarakat yang hidup di Era Digital. Dengan meningkatnya kebutuhan akan infromasi ini, sehingga mendorong para Aktivis dunia IT untuk menyediakan sebuah wadah sebagai tempat bagi manusia untuk bertukar informasi, mengakses informasi, dan membagikan informasi. Maka, Mulailah bermunculan platform-platform yang digunakan, sebagai wadah untuk saling bertukar informasi antara, manusia yang dapat dilakukan dimana saja, kapan saja selama gadget kita, terhubung dengan internet. Wadah tersebut pun dikenal dengan Media Sosial.

Media Sosial adalag salah satu meida online berbasis internet yang dapat membantu penggunanya untuk menyebarkan, mengakses, dan mebuat suatu informasi atau konten, yang disajikan dalam bentuk vlog, wiki, forom, jejaring sosial, dan berbagai macam ruang virtual yang ditopang oleh kecangihan teknologi multimedia yang berkembang saat ini. Blog, jejaring sosial, dan wiki merupakan media sosial yang lebih sering diakses dibangdingkan dengan media sosial lainnya. (Eko Sumadi, Jurnal AtTabsyir, 1, Juni 2016:184). Hal tersebut, dapat menyebabkan apa yang kita unggah di Media Sosial, baik itu berupa tulisan, video, ataupun foto dapat diakses oleh orang banyak, tanpa batasan tertentu dan berdampak terhadap bertambah luasnya jangkaun dari informasi yang kita sampaikan.

Dalam Menyampaikan Pesan Dakwah diperlukan adanya sebuah Teknik Publikasi Dakwah yang dapat menarik perhatian dari objek Dakwah untuk memahami pesan dakwah yang disampaikan. Jagat 'Arsy TV adalah salah satu media yang mempublikasikan dakwah dengan 2 teknik, yakni teknik grafis, dan teknik audiovisual. Pada umumnya, media dakwah yang bergerak dalam teknik audiovisual, maka ia hanya terfokus pada audiovisual saja, dan kurang aktif dalam menggunakan teknik 
grafis, begitupun sebaliknya. Sebagaimana yang terdapat pada dua akun dakwah media sosial yakni Ustadz Abdul Somad official, dan Adi Hidayat Official. Kedau akunterseut, adalah akun dakwah yang menggunzakan teknik audivisual dalam menyampaikan pesan dakwahnya, adapun pengunaan teknik grafis yang berisikan pesan-pesan dakwah sangat jarang sekali ditemukan.

Penelitian yang terdahulu yang juga fokus dalam berdakwah di Media sosial adalah Skripsi yang disusun oleh Ayu Asnani Burhanudin dengan NIM 153100001 Mahasiswa Fakultas Ushuluddin, Adab Dan Dakwah Institut Agama Islam Negeri Parepare, Dengan Judul "Analisis Isi Pesan Dakwah Pada Media Sosial Instagram Dalam Akun Kartun Muslimah", Skripsi yang disusun oleh Evi Novitasari, Mahasiswi Komunikasi Penyiaran Islam Fakultas Ushuluddin, Adab, dan Dakwah Institut Agama Islam Negeri Ponorogo 2020, dengan judul “Dakwah Melalui YouTube", Skripsi yang disusun oleh Septina Wulandari dengan NIM 411206557 dengan judul “Facebook Sebagai Media Dakwah" tahun 2018. Yang membedakan penelitian ini dengan penelitian terdahulu adalah objek dari penelitian yang terfokus pada Teknik Publikasi Media Dakwah Jagat 'Arsy TV. Tujuan dari penelitian ini adalah untuk mengetahui Bagaimana Publikasi Media Dakwah Pada Jagat 'Arsy TV, Untuk mengetahui Faktor Pendukung dan Penghambat pada Publikasi Media Dakwah Pada Jagat 'Arsy TV, dan Hasil Dari Publikasi Media Dakwah Pada Jagat 'Arsy TV. Adapun pendekatan yang digunakan oleh peneliti adalah pendekatan yang berjenis kualitatif, dengan menggunakan metode analisis isi.

\section{LANDASAN TEORITIS}

Teori yang digunakan pada penelitian adalah Teknik Publikasi Dakwah, Metode Dakwah, Wasilah Dakwah, Pesan Dakwah, dan Aspek-aspek viralnya sebuah konten Dakwah. Menurut Wina Sanjaya teknik adalah cara yang digunakan oleh seseorang untuk membantunya dalam mengimplementasikan sebuah metode. Dalam buku yang ditulis oleh Prof. Dr. H. Aboebakar Atjeh, beliau mengatakan bahwa dakwah adalah 
Teknik Publikasi Media Dakwah Jagat 'Arsy TV

suatu bentuk seruan kepada seluruh umat manusia, untuk hidup berdasarkan ajaran Alloh yang benar. Teknik Publikasi Dakwah adalah pendukung dari tiap-tiap metode dakwah yang bertujuan untuk menyebarkan ajaran Islam baik itu dalam bentuk Foto, Video, ataupun audio yang kemudia dipublikasikan di Media Sosial. Prof. Dr. Moh Ali Aziz, dalam buku beliau yang berjudul Ilmu Dakwah mengklasifikasikan Metode dakwah ke dalam enam bentuk, yaitu Metode Ceramah, Metode Diskusi, Metode Konselling, Metode Karya Tulis, dan Metode kelembagaan.

Pada penelitian kali ini, peneliti akan terfokus pada Metode Karya Tulis dengan teknik pembuatan Gambar. Metode ini termasuk dalam kategori dakwah bil al-qalam (dakwah dengan tulisan). Tanpa tulisan, peradaban dunia akan hilang dan punah. Kita dapat memahami Al-Qur'an, Hadits, Fiqh para Imam Madzhab dari tulisan-tulisan yang diterbitkan oleh mereka melalui buku-buku mereka. (Ali Aziz, 2004: 320). Wasilah (media) dakwah adalah alat yang digunakan untuk menyampaikan maddah (ajaran Islam) dakwah kepada mad'u. Untuk menyampaikan ajaran Islam kepada umat, dakwah dapat menggunakan berbagai wasilah. Dr. Hamzah Ya'qub membagi dakwah Wasilah menjadi lima macam, yaitu lisan, tulisan, lukisan, audio visual dan moral/akhlak. (Muhammad Hassan, 2013: 76).

Dalam ilmu komunikasi, pesan dakwah adalah massage, yaitu simbol. Dalam kesusastraan Arab, pesan dakwah disebut maudli 'al-da'wah. Istilah ini lebih tepat dibandingkan dengan istilah materi dakwah yang diterjemahkan dalam bahasa Arab menjadi maaddah al-dakwah. Istilah dakwah dipandang lebih tepat untuk menjelaskan isi dakwah berupa kata-kata, gambar, lukisan, dan sebagainya yang diharapkan dapat memberikan pemahaman bahkan perubahan sikap dan perilaku kepada mitra dakwah (Ali Aziz, 2004:272). Pertama, nilai-nilai positif dalam konten Dakwah. Kedua, Tampilan visual pada meme dapat memberikan provokasi pada emosi dari pembaca. Ketiga, pesan yang disampaikan lebih jelas dan akurat. Keempat, kredibilitas yang dimiliki oleh seseorang yang berada didalam konten meme. Kelima, Posisi atau positioning 
Panji PM, Eunis K

diunggah terkait dengan topik dan konteks yang tengah banyak diminati dan diperbincangkan oleh masyarakat. Keenam, interaksi dari pengguna media sosial.

Hasil Dari penelitian ini berkaitan dengan 3 jenis teknik Publikasi Media Dakwah Pada Jagat 'Arsy TV, yakni Teknik Audiovisual, Teknik Grafis, dan Teknik Prime Time. Adapun Yang menjadi Faktor pendukung dalam Publikasi Media Dakwah pada Jagat 'Arsy TV adalah Pertama, nilai-nilai positif dalam konten Dakwah. Kedua, Tampilan visual pada meme dapat memberikan provokasi pada emosi dari pembaca. Ketiga, pesan yang disampaikan lebih jelas dan akurat. Keempat, kredibilitas yang dimiliki oleh seseorang yang berada didalam konten meme. Kelima, Posisi atau positioning diunggah terkait dengan topik dan konteks yang tengah banyak diminati dan diperbincangkan oleh masyarakat. Keenam, interaksi dari pengguna media sosial. Ketujuh, Youtube menyediakan fitur Thumbnail dan Judul. Sedangkan Faktor penghambat dalam Publikasi Media Dakwah Pada Jagat 'Arsy TV adalah, Pertama, Kurangnya Pengunaan Thumbnail. Kedua, Kurangnya Pegunaan Bingkai Informasi Keempat, Kurang Meratanya Kualitas Peralatan. Kelima, Kurang Teraturnya Waktu dalam Mempublikasikan Konten. Keenam, Belum adanya ahli Desain. Jumlah orang yang telah melihat konten Facebook Jagat 'Arsy TV sebanyak 69.6 ribu akun, dan orang yang Melihat profil dari Halaman Facebook Jagat 'Arsy TV sebanyak 1.658 pada Bulan Maret 2021. Sedangkan YouTube Jagat 'Arsy TV Pada Bulan Juni 2021 YouTube Jagat 'Arsy TV sudah memiliki 17,5 ribu pelanggan, dan telah mengupload sebanyak 550 Video, yang telah ditonton oleh sebanyak 2.678 .810 .

\section{HASIL DAN PEMBAHASAN}

\section{Teknik Grafis}

Teknik grafis yang saat ini banyak diminati dan paling sering digunakan adalah meme. Meme merupakan salah satu teknik dalam menyampaikan pesan Dakwah, yang sangat viral di Media Sosial. Adapun jenis meme yang diunggah pada halaman Facebook Jagat 'Arsy TV adalah meme 
islami, yang bertujuan untuk menyampaikan pesan-pesan keislaman, melaui Meme yang saat ini sangat digemari oleh pengguna dunia maya, khususnya dalam bidang tasawuf dan Thoriqoh. Meme Islami hadir sebagai salah satu bentuk terobosan dalam cara berdakwah untuk menymapiakan ajaran Islam, dan juga dapat dijadikan sebagai media untuk bertabligh, dengan menggunakan bahsa yang ringan, tampilan yang menarik, serta mampu menark perhatian dari para pembaca. (Ryan Alamsyah, Skripsi, 2019: 37-38).

\section{Teknik Audiovisual}

Teknik Publikasi Dakwah yang kedua adalah Teknik Audiovisual. Pada Medai Sosial Facebook Jagat 'Arsy TV, Publikasi Dakwah juga dilakukan dengan mengunggah Audiovisual atau video-video. Adapun jenis Audiovisual yang digunakan adalah jenis Streaming, Yang dimana jenis streaming ini terbagi menjadi dua macam, yaitu Live Streaming dan Pre Record Streaming. Live Streaming, adalah teknik perekaman yang konsep pelaksanaanya hampir sama seperti siaran langsung, yang biasanya dilakukan oleh Televisi. Dalam proses perekaman ini, pemilik konten dapat merekam, sekaligus menyiarkannya secara langsung, melalui akun yang dimilikinya, sehingga host dari video dapat mengetahui secara langsung apa saja yang terjadi disetiap detik pada proses perekaman video. Sedangkan Prerecord Streaming dilakukan dengan konsep merekam terlebih dahulu, setelah itu baru disisarkan kepada media yang dimilikinya. Hots pada prerecord Streaming tidak dapat berinteraksi secara langsung dengan penonoton videonya, berbeda dengan Live Streaming yang dapat memungkinkan Host untuk berinteraksi secara langsung dengan Penonton Videonya.

\section{Teknik Prime Time}

pada Umumnya Manusia menggunakan Media Sosial sebagai sarana Media Hiburan. Oleh karena demikian, penting bagi pegiat Media Sosial untuk mengetahui waktu-waktu kapan saja, yang dimana pada waktu tersebut mayoritas orang mengakses Media Sosial mereka.

Waktu-waktu tersebut pun disebut prime time. Prime time adalah Jam Tayang Utama

(Wikipedia, 
Panji PM, Eunis K

https://id.m.wikipedia.org/wiki/Jam_tayang_utama Diakses pada tanggal 18 Maret 2021, pada Pukul 13.33). Jam tayang utama adalah waktu orang banyak berinteraksi dengan Gadget mereka. Berdasarkan pemamparan dari Salah Satu pengelolah Jagat 'Arsy TV yang bernama Pak Mursyid (wawancara, 23 Februari 2021), beliau mengatakan terdapat 3 waktu yang sanagat baik untuk meengungah Postingan kita, Sehingga bisa dijangkau oleh banyak orang, yaitu:

a.) Pagi, ba'da Shubuh. Waktu ini termasuk prime time dikarenakan orang-orang sebelum beraktifitas, mereka melakukan interaksi dengan media Sosial mereka terlebih dahulu, entah itu untuk mencari Informasi, Hiburan, ataupun pekerjaan. b.) Siang, pada pukul 11.00-13.00. Waktu ini adalah waktu orang-orang beristirahat dari pekerjaan mereka, sehingga beberapa dari mereka mengakses Media Sosial mereka, sebagai sara untuk melepaskan penat dari pekerjaan. c.) Sore, pada pukul 17.00 hingga 21.00. waktu ini adalah waktu orang-orang pulang dari pekerjaan mereka. (Internet Marketing, https://internetmarketing.co.id Diakses pada tanggal 18 maret 2021 pada pukul 13.48)

\section{Faktor Pendukung dan Penghambat}

\section{faktor Pendukung}

Faktor pendukung dalam Publikasi Media Dakwah pada Jagat 'Arsy TV adalah Pertama, nilai-nilai positif dalam konten Dakwah. Kedua, Tampilan visual pada meme dapat memberikan provokasi pada emosi dari pembaca. Ketiga, pesan yang disampaikan lebih jelas dan akurat. Keempat, kredibilitas yang dimiliki oleh seseorang yang berada didalam konten meme. Kelima, Posisi atau positioning diunggah terkait dengan topik dan konteks yang tengah banyak diminati dan diperbincangkan oleh masyarakat. Keenam, interaksi dari pengguna media sosial. Ketujuh, Youtube menyediakan fitur Thumbnail dan Judul.

\section{Faktor penghambat}

Faktor penghambat dalam Publikasi Media Dakwah Pada Jagat 'Arsy TV adalah, Pertama, Kurangnya Pengunaan Thumbnail. Kedua, Kurangnya Pegunaan Bingkai Informasi Keempat, Kurang Meratanya Kualitas 
Teknik Publikasi Media Dakwah Jagat 'Arsy TV

Peralatan. Kelima, Kurang Teraturnya Waktu dalam Mempublikasikan Konten. Keenam, Belum adanya ahli Desain.

\section{PENUTUP}

Teknik Publikasi Dakwah Jagat 'Arsy TV terbagi dalam dua jenis, yakni Teknik Grafis/meme dan Teknik Audiovisual, dan Teknik Prime Tume. Teknik Grafis/mem adalah teknik dengan cara membuat sebuah gambar yang berisikan pesan dakwah yang dikutip dari perkataan Ulama. adapun perkataan Ulama yang dikutip adalah perkataan Dari Syaikh Muhammad Abdul Gaos Saefulloh Maslul. Teknik Prime Time adalah adalah teknik publikasi dengan memperhatikan Waktu-waktu tertentu yang menjadi prioritas orang-orang dalam menggunakan Media sosial.

Terdapat 7 faktor pendukung dalam Teknik Publikasi Dakwah Jagat 'Arsy TV. Pertama, nilai-nilai positif yang disampiakan tidak mengandung maksud ataupun tujun untuk menyinggun dan menyindri. Kedua, Tampilan visual pada meme dapat meberikan provokasi pada pemosi dari pembaca, baik itu emosi positif atau negatif. Ketiga, pesan yang disampiakan dalam bentuk meme cenderung lebih jelasn dan akurat.. Keempat, kredibilitas yang dimiliki oleh seseorang yang berada didalam konten meme, mebrikanpengaruh terhadap luasnya jangkauaun dan cakupan informasi dari suatu meme. Kelima, Posisi atau positioning diunggah terkait dengan topik dan konteks yang tengah banyak diminati dan diperbicangkan oleh masyarakat. Keenam, interaksi dari pengguna media sosial, berupa menyebarkan, memberikan komentar, dan menyukai konten yang diunggah. Ketujuh, Youtube menyediakan fitur yang dapat menarik perhatian publik untuk menyaksikan video yang kita publikasikan. Fitur tersebut disebut dengan Thumbnail dan Judul.

Sedangkan Faktor penghamabat dalam Publikasi Dakwah Media Sosial Jagat 'Arsy TV adalah, Pertama, Kurangnya Pengunaan Thumbnail. Kedua, Kurangnya Pegunaan Bingkai Infotmasi Pada Video Live Streaming Jagat 'Arsy TV. Ketiga, Kurangnya SDM (Sumber Daya Manusia. Keempat, Kurang Meratanya Kualiats Peralatan yang dimilki tiap Anggota. Kelima, Kurang Teraturnya Waktu dalam 
Panji PM, Eunis K

Mempublikasikan Konten. Keenam, Belum adanya ahli Desain. saran dalam penelitian ini adalah, Hasil dari penelitian ini dapat memberikan kontibusi terutama kepada pegiat dakwah melalui jejaring media sosial Hasil penelitian ini dapat memberikan sebuah pemahaman kepada para pendakwah pada umumnya, akan pentingnya untuk berdakwah di Media Sosial Hasil Penelitian ini dapat menjadikan rujukan, bagi Lembaga STID Sirnarasa dalam mningkatkan sara Media Informasi, khusunya Kanal YouTube.

\section{DAFTAR PUSTAKA}

Aziz, Moh Ali. (2017). Ilmu Dakwah. Jakarta : Kencana

Hassan, Mohammad. (2013). Metodologi Pengembangan Ilmu Dakwah. Surabaya : Pena Salsabila

Nazarudin, Mgs. H. (2020). Manajemen Strategik. Palembang : CV. Amanah

Nurdin, Ismail dan Sri Hartati. (2019). Metodologi Penelitian Sosial. Surabaya : Media Sahabat Cendekia

Omar, Toha Yahya. 2004. "Islam \& Dakwah". (Jakarta: PT. Al-Mawardi Prima) Siyoto, Sandu dan Ali Sodik. (2015). Dasar Metodologi Penelitian. Yogyakarta: Literasi Media Publishing

Solatun. 2007. "Islam dan Etika Komunikasu". (Jakarta: Imagine)

\section{Skripsi:}

Ayu Asnani Burahnudin, "Analisis Isi Pesan Dakwah Pada Media Sosial Instagram Dalam Akun Kartun Muslimah” (Parepare : IAIN Parepare 2020)

Dewi Oktaviani, "Pengaruh Media Sosial Terhadap Gaya Hidup Mahasiswa Iain Metro”. (Metro: IAIN Metro 2019)

Evi Novitasari, "Dakwah Melalui Media Sosial YouTube (Analisis Media Siber Dalam Etnografi Virtual Pada Channel YouTube Transformasi Iswahyudi 2020)

Imas Mutiawati, "Dakwah Di Media Sosial (Studi Fenomenologi Dakwah di Instagram)" (Semarang : UIN Wali Songo 2018)

Ririh Nur Aini Putri, "Komunikasi Dakwah Melalui Media Audio Visual Dalam Menanamkan Akhlak Pada Santri Tpa Aisyiyah Desa Margasari Kecamatn Labuhan-Maringgai Kabupaten Lampung Timur” (Lampung: UIN Raden Intan 2017) 
Teknik Publikasi Media Dakwah Jagat 'Arsy TV

Yoghi Ridho Firdaus, "Dakwah Melalui Konten Video Ceramah Dalam Media Youtube” (Salatiga: IAIN Salatiga 2018)

\section{Jurnal :}

Jamaluddin, Opik "Peran Wakil Talqin dalam Pengembangan DakwahTarekat". Jurnal Anida (Aktualisasi Nuansa Ilmu Dakwah) Volume 18, Nomor 2, 2018: 159-180 Dudung Abdul Rohman, “Komunikasi Dakwah Melalui Media Sosial”. Jurnal Balai Diklat Keagamaan Bandung Volume XIII Nomor 2 Tahun 2019: 121-13 Zulfikar Ghazali, "Pemanfaatan Media Sosial Facebook Sebagai Media Dakwah Dalam Masyarakat Virtual”. Jurnal Al-Muttaqin. Vol. IV, No. 1, Desember 2016 - Mei 2017

\section{Internet :}

https://m.youtube.com/channel/UCx2I4CFp9UxukKrwFif5uLg/about Di akses pada tanggal 19 Maret 2021, Jam 08.02

https://internetmarketing.co.id Diakses pada tanggal 18 maret 2021 pada pukul 13.48

https://id.m.wikipedia.org/wiki/Jam_tayang_utama Diakses pada tanggal 18 Maret 2021, pada Pukul 13.33

https://www.baktikominfo.id/id/informasi/pengetahuan/pengertian_streaming_s erta_jenis_dan_penerapannya-1065, Diakses pada tanggal 17 Maret 2021, Pukul 17:01

https://m.merdeka.com/teknologi/data-terkini-pengguna-facebook-diindonesia.html, diakses pada tanggal 27 Maret 2021, pukul 09.59 https://m.youtube.com/channel/UCx2I4CFp9UxukKrwFif5uLg/about Di akses pada tanggal 19 Maret 2021, Jam 08.02 